\title{
THE SIZE AND MORPHOLOGICAL FEATURES OF GRAINS OF NATIVE STARCH OF DIFFERENT BOTANICAL ORIGIN
}

\author{
A. Zabolotec, A. Ermakov \\ Belarusian National Technical University \\ V. Litvyak \\ Scientific and Practical Centre for Foodstuffs of the National Academy of Sciences \\ of Belarus
}

\begin{tabular}{l} 
Key words: \\
Starch \\
Grains \\
Size \\
Morphology \\
\multicolumn{1}{c}{ Article history: } \\
Received 15.01.2018 \\
Received in revised form \\
03.02.2018 \\
Accepted 23.02.2018 \\
\hline
\end{tabular}

Corresponding author:

A. Zabolotec

E-mail:

tiro@bntu.by

\section{ABSTRACT}

The sizes and morphological features of the seeds of native starch of different botanical origin isolated from plants of Solanum tuberosum L., Zea mays L., Manihot utilissima L. and Manihot palmate L., Red leoti L., genus Triticum, Tritikale, Secale cereale L., Hordeum vulgare L., Avena sativa L., Oryza sativa L., Pisum sativum L., Amaranthus tricolor L., Cicer arietinum L. are investigated in the paper. The main structural characteristic of the structure of native starch that is a natural polymer in which the monomers ( $\alpha$-D-glucopyranose residues) are bound by $\alpha$ $(1 \rightarrow 4)$ - and $\alpha-(1 \rightarrow 6)$-glucoside bonds, forming amylose (polysaccharide of linear structure) and amylopectin (polysaccharide of branched structure) which is responsible for its physical-chemical properties is a starch corn (granule). Modern methods of obtaining native starch from plant raw materials of different botanical origin are analyzed. A wide variety of forms of starch grains was found to be regularly and irregularly oval, round, polyhedral. The dimensions of the starch grains ranged from 60,0 to 0,5 microns. The plant Solanum tuberosum $\mathrm{L}$ is noted to have maximal sizes of starch grains., and Amaranthus tricolor L minimal sizes. Depending on the average size, starch grains can be arranged in a row due to the decreasing order: potato $(21,7 \pm$ $\pm 1,22$ microns), rye $(21,2 \pm 2,36$ microns), pea $(20,4 \pm 2,57 \mathrm{mi}-$ crons), nutaceous (14,8 $\pm 0,93$ microns), tritical (13,2 $\pm 1,75 \mu \mathrm{m})$, wheat $(12,4 \pm 1,90$ microns), sorghum (11,0 $\pm \pm 0,76$ microns $)$, barley (10,9 $\pm 1,15$ microns), tapioca (10,6 $\pm 0,50$ microns), corn $(9,8 \pm 0,42$ micron), oatmeal $(7,39 \pm 0,87$ microns $)$, rice $(5,3 \pm$ 0,29 microns), amaranth (1,1 $\pm 0,04$ microns). The largest size of starch grains was found in potato starch, and the smallest - in amaranth starch. It has been established that 7 native starches (sorghum, barley, oat, pea, chickpea, amaranth and corn) have monomodal distribution of starch grains in size (1-fractional), 4 (wheat, tritical, potato and tapioca) - bimodal (2-fractional), 2 (rye and rice) - trimodal (3-fractional). The gelatinization temperature, the amount of bound and free moisture, the viscosity of the starch paste, the ratio of starch fractions, the color of the iodine test, and other physical-chemical properties determine the specifics of the size and shape of the starch grains.

DOI: $10.24263 / 2225-2924-2018-24-1-31$ 


\title{
РАЗМЕРЫ И МОРФОЛОГИЧЕСКИЕ ОСОБЕННОСТИ ЗЕРЕН НАТИВНОГО КРАХМАЛА РАЗНОГО БОТАНИЧЕСКОГО ПРОИСХОЖДЕНИЯ
}

\author{
А.А. Заболотец, А.И. Ермаков \\ Белорусский национальный технический университет
}

В.В. Литвяк

Научно-практический центр НАН Беларуси по продовольствию

В статье исследованы размеры и морфологические особенности зерен нативного крахмала разного ботанического происхождения, выделенного из растений Solanum tuberosum L., Zea mays L., Manihot utilissima L. u Manihot palmate L., Red leoti L., poдa Triticum, Tritikale, Secale cereale L., Hordeum vulgare L., Avena sativa L., Oryza sativa L., Pisum sativum L., Amaranthus tricolor L., Cicer arietinum L. Основной структурной характеристикой строения нативного крахмала - природного полимера, в котором мономеры (остатки $\alpha$ -

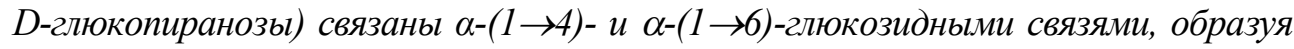
амилозу (полисахарид линейного строения) и амилопектин (полисахарид разветвленного строения), обуславливающей его физико-химические свойства, является крахмальное зерно (гранула). Проанализированы современные способы получения нативного крахмала из растительного сырья разного ботанического происхождения. Выявлено большое разнообразие форм крахмальных зерен правильной и неправильной овальной, округлой, многогранной формы.

Размеры крахмальных зерен колебались пределах 60,0-0,5 мкм. Максимальные размеры крахмальных зерен отмечены у растения Solanum tuberosum L., а минимальный - y Amaranthus tricolor L. B зависимости от среднего размера крахмальные зерна можно расположить в ряд по уменьшению: картофельный $(21,7 \pm 1,22$ мкм), ржаной $(21,2 \pm 2,36$ мкм), гороховый (20,4 2,57 мкм), нутовый $(14,8 \pm 0,93)$, тритикалевый $(13,2 \pm 1,75$ мкм), пшенич-

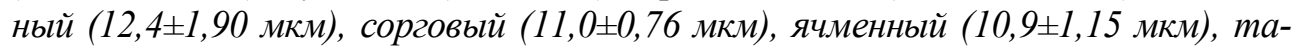

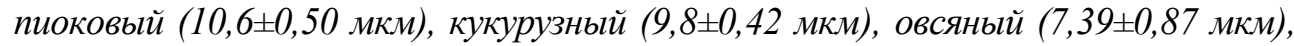

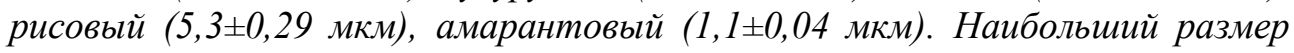
крахмальных зерен был отмечен у картофельного крахмала, а наименьший размер - у амарантового крахмала.

Установлено, что у семи нативных крахмалов (соргового, ячменного, овсяного, горохового, нутового, амарантового и кукурузного) распределение крахмальных зерен по размерам мономодальное (1-фракционное), у четырех (пшеничного, тритикалевого, картофельного и тапиокового) - бимодальное (2-фракиионное), у двух (ржаного и рисового) - тримодальное (3-фракиионное). Температура клейстеризации, количество связанной и свободной влаги, вязкость крахмального клейстера, соотномение крахмальных фракиий, ивет йодной пробы и другие физико-химические свойства обуславливаются (определяются) особенностями размера и формы крахмальных зерен.

Ключевые слов: крахмал, зерна, размер, морфология. 
Постановка проблемы. Ассортимент продукции крахмало-паточного производства довольно велик и составляет несколько сот наименований [1-10]. В качестве основного сырья при получении крахмала и крахмалпродуктов используют картофель, кукурузу, пшеницу, рожь, ячмень, рис, гречиху, тапиоку и др. Кроме нативного крахмала вырабатываются патоки различного углеводного состава (низкоосахаренная, карамельная, высокоосахаренная, мальтозная, декстрин-мальтозная), мальтоза, мальтин, кристаллическая глюкоза, а также глюкозные, глюкозо-фруктозные и фруктозные сиропы. Выпускается большой ассортимент модифицированных крахмалов и декстринов [1-10].

Крахмал и крахмалопродукты играют важную роль в народном хозяйстве [1-8]. Они широко используются во многих отраслях пищевой промышленности: кондитерской, хлебопекарной, консервной, пищеконцентратной, молочной, мясной, а также в текстильной, бумажной, кожевенной, полиграфической, фармацевтической промышленности, в металлургии, в быту. Кроме того, крахмал и его производные применяют в химической промышленности при производстве сорбита, молочной кислоты, глицерина, ацетона, бутанола, лаков, различных плёнок и т.д.

При разработке современных технологий глубокой переработке растительного крахмалосодержащего сырья (технологии получения нативных и модифицированных крахмалов) важнейшим аспектом является изучение размеров и морфологической структуры крахмальных зерен.

Цель статьи: исследование размеров и морфологических особенностей зерен нативного крахмала разного ботанического происхождения.

Объект и методы исследования. Объектом исследований являлись нативные крахмалы: картофельный по ГОСТ 7699 [9], кукурузный по ГОСТ 7697 [10], тапиоковый по техническому норматривному правовому акту (ТНПА), пшеничный по ТНПА, рисовый по ТНПА, ржаной по ТНПА, гороховый по ТНПА, амарантовый по ТНПА, ячменный по ТНПА, сорговый по ТНПА, тритикалевый по ТНПА.

Сканирующие электронные микрофотографии зерен крахмала получены при помощи сканирующего (растрового) электронного микроскопа LEO 1420 (Германия).

Металлизацию препаратов нативного крахмала осуществляли золотом в вакуумной установке ЕМITECH K 550X.

Размеры зерен крахмала оценивались с использованием компьютерных средств по общепринятым методикам. С помощью MS Excel рассчитаны средние значения размеров крахмальных гранул и определены границы доверительного интервала, а также построены графики распределения крахмальных зерен по размеру [11].

Результаты и их обсуждение. Зерна нативного крахмала, выделенные из растительных клеток различного ботанического происхождения, значительно различаются как по форме, так и по размерам, что во многом определяет технологические особенности получения крахмала, его дальнейшую, при необходимости, модификацию и последующее использование [12-14]. 
Сканирующие электронные микрофотографии зерен нативного крахмала различного ботанического происхождения (картофельного, кукурузного, тапиокового, пшеничного, рисового, ржаного, горохового, амарантового, ячменного, соргового, тритикалевого) представлены на рис. $1-4$.

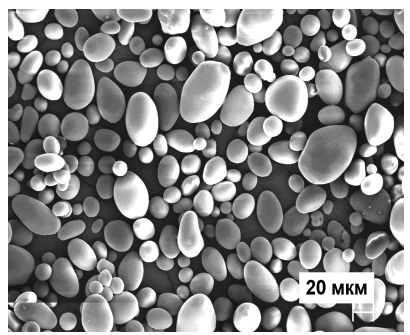

a

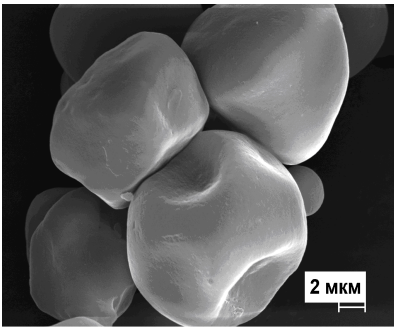

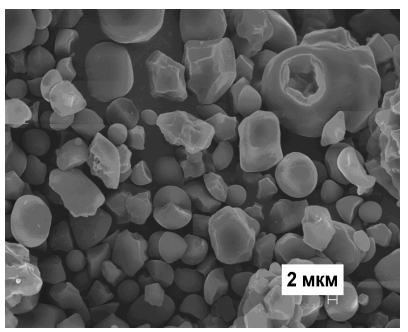

6

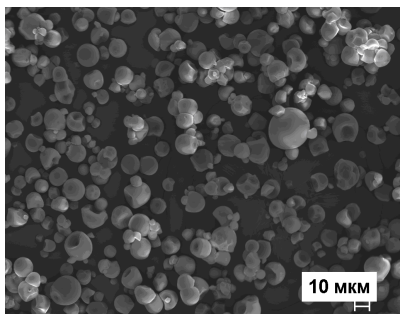

$\Gamma$

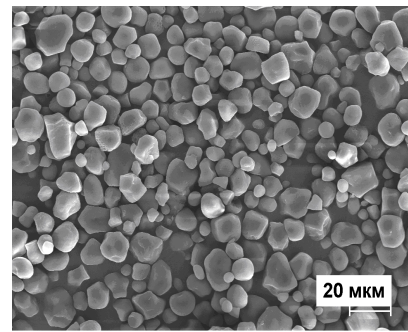

B

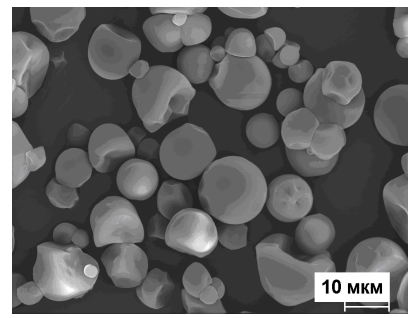

Рис. 1. Сканирующие электронные микрофотографии зерен нативного крахмала: a - картофельный, б - овсяный, в - кукурузный, г — тапиоковый

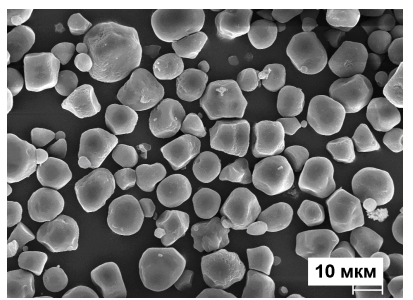

a

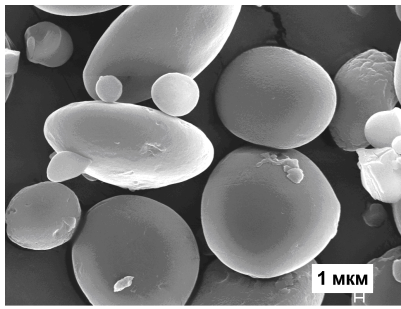

6

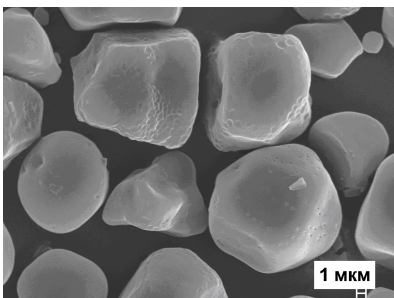

a

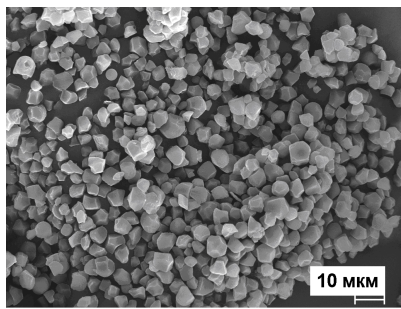

B

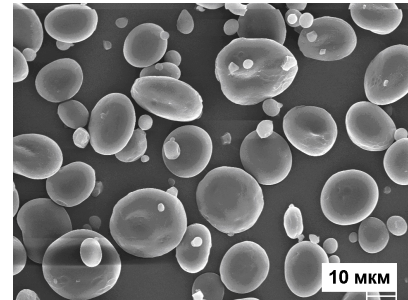

6

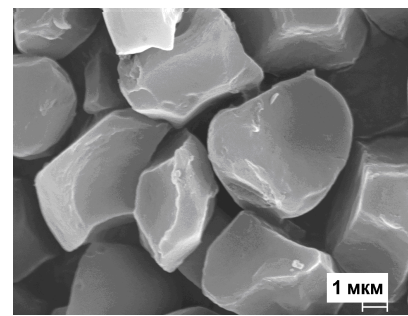

B

Рис. 2. Сканирующие электронные микрофотографии зерен нативного крахмала: a - сорго, б - пшеничный, в - рисовый 


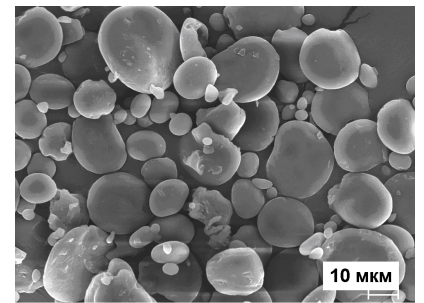

a

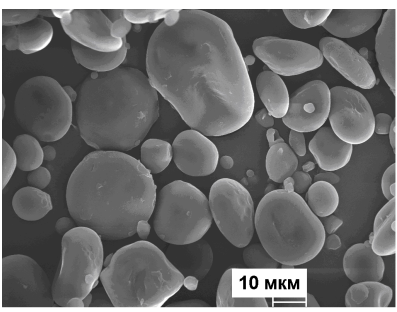

б

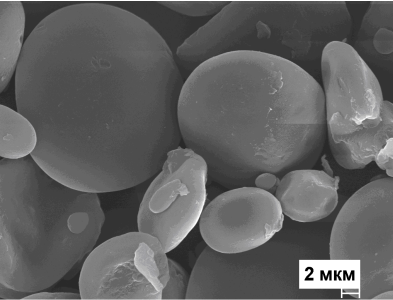

$\mathrm{a}$

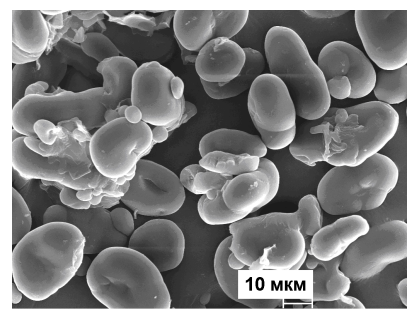

B

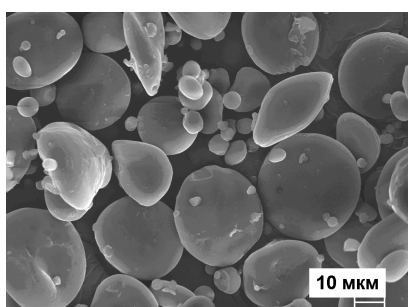

6

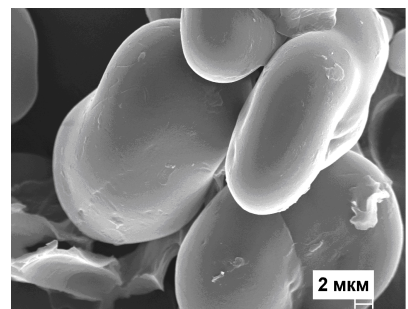

B

Рис. 3. Сканирующие электронные микрофотографии зерен нативного крахмала: a — тритикале, б - ржаной; в — гороховый

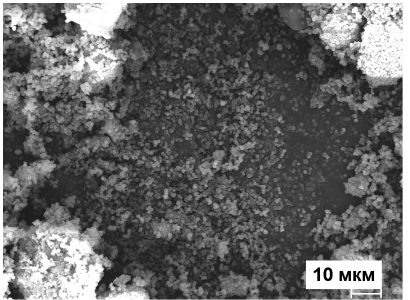

a

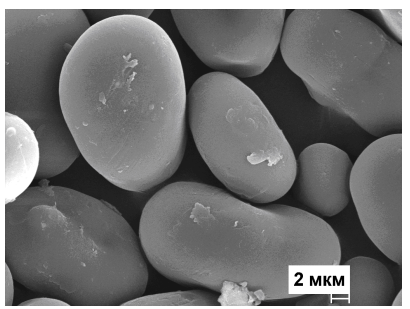

6

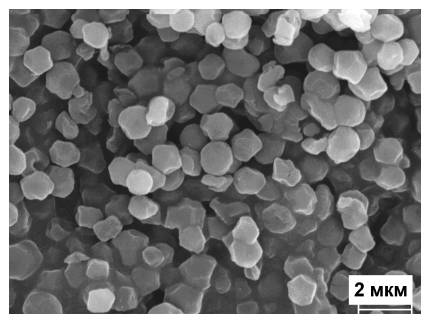

a

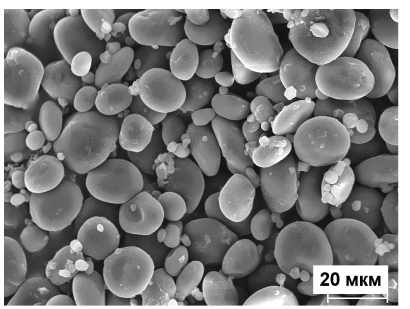

B

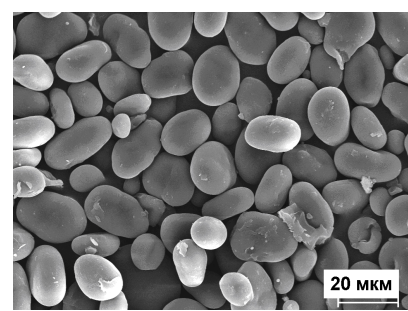

6

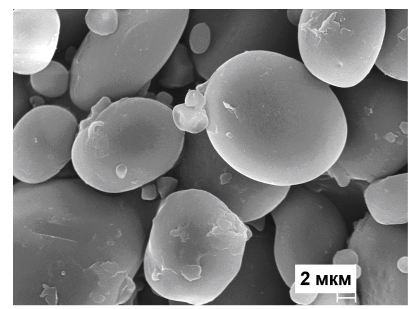

B

Рис. 4. Сканирующие электронные микрофотографии зерен нативного крахмала: a - амарантовый, б - нутовый, в - ячменный

На рис. 5 и 6 показан гранулометрический анализ зерен нативного крахмала разного ботанического происхождения (распределение зерен нативного крахмала по размерам). 


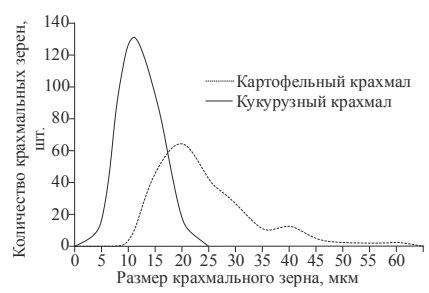

a

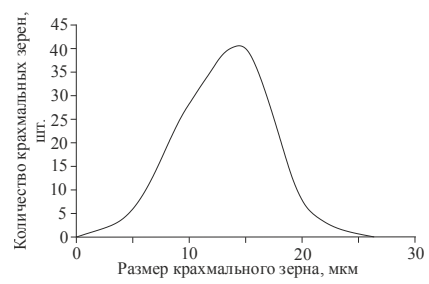

$\Gamma$

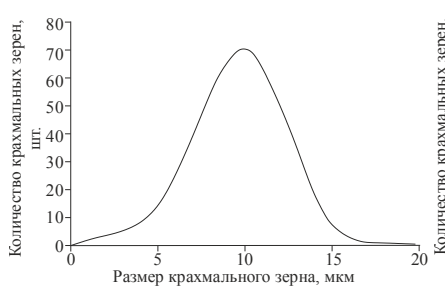

6

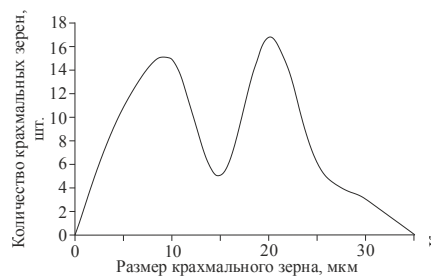

д

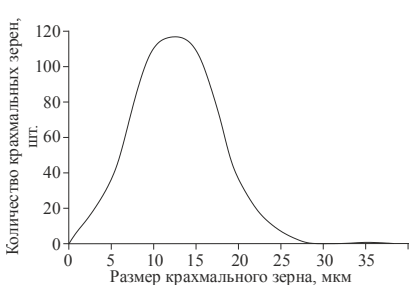

B

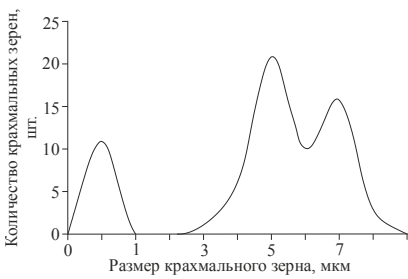

e

Рис. 5. Гранулометрический анализ зерен нативного крахмала:

a - картофельный и кукурузный, в - овсяный, в - тапиоковый, г - сорго, д - пшеничный, е - рисовый

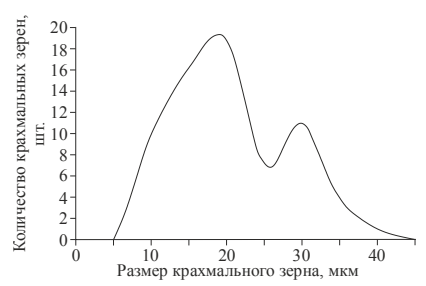

a

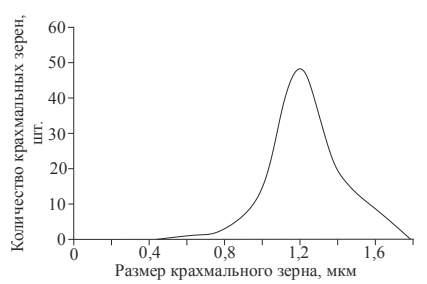

$\Gamma$

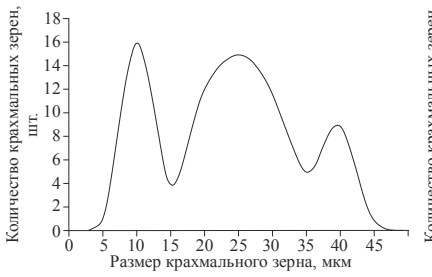

6

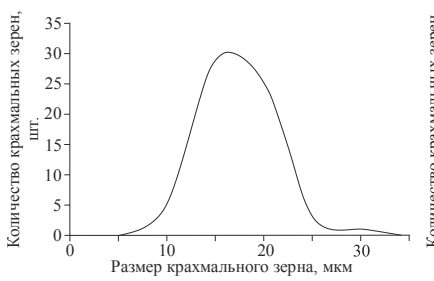

Д

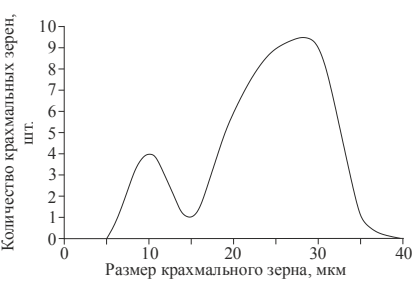

B

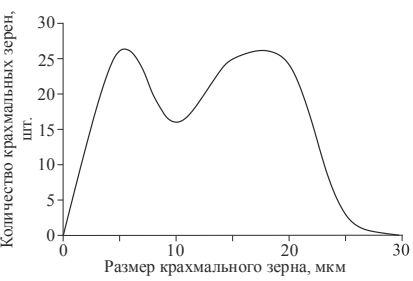

e

Рис. 6. Гранулометрический анализ зерен нативного крахмала:

a — тритикале, б - ржаной, в — гороховый, г — амарантовый, д — нутовый, е - ячменный

Гранулометрический анализ зерен нативного крахмала проведен на основании результатов, приведенных в таблице, где показаны средний, минимальный и максимальный размеры зерен нативных крахмалов разного ботанического происхождения с особенностями статистической обработки исследованной выборки. 
FOOD TECHNOLOGY

Таблица 1. Морфологическая характеристика нативных крахмалов различного ботанического происхождения

\begin{tabular}{|c|c|c|c|c|c|c|c|}
\hline \multirow{2}{*}{ Параметры } & \multicolumn{7}{|c|}{ Нативные крахмалы } \\
\hline & 1 & 2 & \multicolumn{2}{|c|}{\begin{tabular}{|l|l}
3 & \\
\end{tabular}} & 4 & 5 & 6 \\
\hline$d_{\text {сред. }}$ & 21,2 & 12,4 & \multicolumn{2}{|c|}{13,2} & 11,0 & 10,9 & 5,3 \\
\hline Стандартная ошибка & 1,19 & 0,97 & \multicolumn{2}{|c|}{0,88} & 0,38 & 0,58 & 0,15 \\
\hline Медиана & 21,8 & 11,3 & \multicolumn{2}{|c|}{12,7} & 11,0 & 11,4 & 5,2 \\
\hline Мода & 22,4 & 2,8 & \multicolumn{2}{|c|}{13,1} & 12,2 & 4,5 & 4,1 \\
\hline $\begin{array}{l}\text { Стандартное } \\
\text { отклонение }\end{array}$ & 10,27 & 7,31 & \multicolumn{2}{|c|}{7,24} & 3,49 & 5,63 & 1,11 \\
\hline Дисперсия выборки & 105,4 & 53,5 & \multicolumn{2}{|c|}{52,48} & 12,19 & 31,72 & 1,23 \\
\hline Эксцесс & $-0,9$ & $-1,27$ & \multicolumn{2}{|c|}{$-0,67$} & 0,16 & $-1,34$ & $-0,59$ \\
\hline Асимметричность & 0,1 & 0,26 & \multicolumn{2}{|c|}{0,51} & 0,09 & 0,1 & 0,06 \\
\hline Интервал & 37,9 & 24,3 & \multicolumn{2}{|c|}{26,7} & 18,2 & 18,4 & 5,2 \\
\hline$d_{\min }$ & 4,9 & 2,8 & \multicolumn{2}{|c|}{4,0} & 3,5 & 3,0 & 2,7 \\
\hline$d_{\max }$ & 42,8 & 27,1 & \multicolumn{2}{|c|}{30,7} & 21,7 & 21,4 & 7,9 \\
\hline $\begin{array}{c}\text { Уровень надежности } \\
(95,0 \%)\end{array}$ & 2,36 & 1,90 & \multicolumn{2}{|c|}{1,75} & 0,76 & 1,15 & 0,29 \\
\hline Верхняя граница & 23,5 & 14,3 & \multicolumn{2}{|c|}{15} & 11,7 & 12,1 & 5,6 \\
\hline Нижняя граница & 18,8 & 10,5 & 11 & & 10,2 & 9,8 & 5 \\
\hline & & & Наті & ные кр & ахмалы & & \\
\hline Параметры & 7 & 8 & 9 & 10 & 11 & 12 & 13 \\
\hline$d_{\text {сред. }}$ & 20,4 & 14,8 & 1,1 & 10,6 & 21,7 & 9,8 & 7,39 \\
\hline Стандартная ошибка & 1,25 & 2,46 & 0,02 & 0,26 & 0,62 & 0,21 & 0,43 \\
\hline Медиана & 20,8 & 14,5 & 1,1 & 10,1 & 19,0 & 9,7 & 6,57 \\
\hline Мода & н/д & 15,8 & 1,2 & 8,8 & 17,1 & 12,7 & 5,09 \\
\hline $\begin{array}{c}\text { Стандартное } \\
\text { отклонение }\end{array}$ & 6,87 & 3,69 & 0,18 & 4,43 & 8,99 & 3,38 & 2,56 \\
\hline Дисперсия выборки & 47,22 & 13,59 & 0,03 & 19,63 & 80,88 & 11,44 & 6,57 \\
\hline Эксцесс & 0,02 & 0,17 & 0,71 & 0,66 & 2,2 & $-0,49$ & 0,66 \\
\hline Асимметричность & $-0,74$ & 0,07 & $-0,32$ & 0,54 & 1,4 & 0,37 & 1,04 \\
\hline Интервал & 26,3 & 19,6 & 1,0 & 28,4 & 52,3 & 15,5 & 10,96 \\
\hline$d_{\min }$ & 6,1 & 6,0 & 0,5 & 2,8 & 7,7 & 3,6 & 3,96 \\
\hline$d_{\max }$ & 32,3 & 25,6 & 1,5 & 31,2 & 60,0 & 19,2 & 14,91 \\
\hline $\begin{array}{c}\text { Уровень надежности } \\
(95,0 \%)\end{array}$ & 2,57 & 0,93 & 0,04 & 0,50 & 1,22 & 0,42 & 0,87 \\
\hline Верхняя граница & 23,0 & 15,7 & 1,2 & 11,1 & 22,9 & 10,2 & 8,25 \\
\hline Нижняя граница & 17,8 & 13,9 & 1,1 & 10,1 & 20,5 & 9,3 & 6,52 \\
\hline
\end{tabular}

Примечание: 1 - ржаной, 2 - пшеничный, 3 - тритикалевый, 4 - сорговый, 5 - ячменный, 6 - рисовый, 7 - гороховый, 8 - нутовый, 9 - амарантовый, 10 - тапиоковый, 11 - картофельный, 12 - кукурузный, 13 - овсяный.

Анализ морфологической характеристики зерен нативных крахмалов показал, что крахмальные зерна имеют преимущественно следующую форму: у ржаного и ячменного - овальную и округлую, у пшеничного и тритикалевого - правильную овальную и округлую, у горохового и картофельного неправильную овальную, у овсяного и тапиокового - неправильную округлую, у рисового и кукурузного - неправильную многогранную, у соргового овальную и многогранную, у нутового — правильную овальную, у амарантового - многогранную (рис. 1-4). 
Установлено, что средний размер зерен нативного ржаного, пшеничного, тритикалевого, соргового, ячменного, рисового, горохового, нутового, амарантового, тапиокового, картофельного, кукурузного, овсяного соответственно, составит: $21,2( \pm 2,36) ; 12,4( \pm 1,90) ; 13,2( \pm 1,75) ; 11,0( \pm 0,76) ; 10,9( \pm 1,15)$; $5,3$ ( $\pm 0,29) ; 20,4( \pm 2,57) ; 14,8( \pm 0,93) ; 1,1( \pm 0,04) ; 10,6( \pm 0,50) ; 21,7( \pm 1,22) ; 9,8$ $( \pm 0,42) ; 7,39( \pm 0,87)$ мкм (табл. 1). При этом минимальный и максимальный размер зерен нативного ржаного, пшеничного, тритикалевого, соргового, ячменного, рисового, горохового, нутового, амарантового, тапиокового, картофельного, кукурузного колебался в пределах: 4,9-42,8; 2,8-27,1; 4,030,$7 ; 3,5-21,7 ; 3,0-21,4 ; 2,7-7,9 ; 6,1-32,3 ; 6,0-25,6 ; 0,5-1,5 ; 2,8-31,2$; $7,7-60,0 ; 3,6-19,2 ; 3,96-14,91$ мкм (табл. 1).

Все исследованные нативные крахмалы в зависимости от среднего размера крахмальных зерен можно расположить в ряд по уменьшению $(\rightarrow)$ : картофельный $\rightarrow$ ржаной $\rightarrow$ гороховый $\rightarrow$ нутовый $\rightarrow$ тритикалевый $\rightarrow$ пшеничный $\rightarrow$ сорговый $\rightarrow$ ячменный $\rightarrow$ тапиоковый $\rightarrow$ кукурузный $\rightarrow$ овсяный $\rightarrow$ рисовый $\rightarrow$ амарантовый. Наибольший размер крахмальных зерен был отмечен у картофельного крахмала, а наименьший размер - у амарантового крахмала.

У семи типов нативных крахмалов (соргового, ячменного, овсяного, горохового, нутового, амарантового и кукурузного) распределение крахмальных зерен по размерам мономодальное (четко выделена одна фракция), у четырех типов нативных крахмалов (пшеничного, тритикалевого, картофельного и тапиокового) распределение крахмальных зерен по размерам бимодальное (двухфракционное), а у двух типов нативных крахмалов (ржаного и рисового) распределение крахмальных зерен по размерам тримодальное (трехфракционное) (рис. 5 и 6).

Крахмалосодержащим сырьем для получения нативного картофельного крахмала являются клубней растений картофеля Solanum tuberosum L., нативного кукурузного (маисового) крахмала - зерна растения кукурузы Zea mays L., нативного тапиокового крахмала - клубней растений Manihot utilissima L. и Manihot palmate L., навного соргового крахмала - растения восковидного сорго Red leoti L., нативного пшеничного крахмала — зерна растений рода Triticum, нативного тритикалевого крахмала - зерна злакового растения тритикале (Tritikale, от лат. triticum - пшеница и от лат. secale - рожь) гибрид пшеницы и ржи, нативного ржаного крахмала - зерен растений Secale cereale L., нативного ячменного крахмала - зерна растения Hordeum vulgare L., нативного овсяного крахмала - зерна растения овса посевного Avena sativa L., нативного рисового крахмала - зерен растений риса Oryza sativa L., нативного горохового крахмала — растения гороха посевного Pisum sativum L., нативного амарантового крахмала - растения щирицы трехцветной Amaranthus tricolor L. или других растений рода Amaranthus, нативного нутового крахмала - растения нута культурного Cicer arietinum L.

Нативный крахмал - природный полимер, в котором мономеры (остатки $\alpha$-D-глюкопиранозы) связаны $\alpha-(1 \rightarrow 4)-$ и $\alpha-(1 \rightarrow 6)$-глюкозидными связями, образуя амилозу (полисахарид линейного строения) и амилопектин (полисахарид разветвленного строения). Крахмальные фракции (амилоза и амилопектин) компактно упакованы в крахмальные зерна (или гранулы) $[1-3 ; 6-7 ; 12]$. 
Источник крахмалосодержащего сырья и особенности структурной организации нативного крахмала во многом определяют технологические приемы, применяемые для максимально полного и щадящего извлечения зерен нативного крахмала из растительной клетки. Для получения нативного крахмала требуется подготовить к переработке растительное крахмалосодержащее сырье, разрушить растительную клетку, извлечь нативный крахмал, отмыть его при помощи чистой воды от сопутствующих примесей, обезвожить, высушить, расфасовать и упаковать. Так, известны способы переработки картофеля на крахмал с использованием разнообразных технологических схем, оснащенных различными видами применяемого для этих целей технологического оборудования. Однако независимо от аппаратурного оформления каждый из этих способов включает стадии производства, которые свойственны всем современным технологиям производства картофельного крахмала: подготовка картофеля к переработке, измельчение, выделение картофельного (клеточного) сока и мезги, очистка крахмала, его обезвоживание и сушка $[1 ; 3 ; 6 ; 7]$.

В настоящее время наиболее рациональным считается способ получения нативного картофельного крахмала, предусматривающий подготовку к переработке и измельчение крахмалсодержащего сырья, использование многоступенчатой гидроциклонной установки, на которой осуществляются операции разделения тонкоизмельченного крахмалсодержащего сырья на крахмальную суспензию и смесь мезги с другими побочными продуктами, а также впоследствии осуществляют частичное сгущение крахмальной суспензии, с последующим обезвоживание, сушкой удалением металломагнитных примесей, фасовкой, упаковкой, маркировкой и транспортированием крахмала [7; 15].

Способы переработки зерна кукурузы на крахмал, предусматривающий пять обязательных стадий: предварительное размягчение структуры зерна кукурузы путем замачивания его в кислой среде, выделение и промывание зародыша, выделение и промывание мезги, выделение и концентрирование белка, промывание крахмала и его сушка $[7 ; 15]$.

Наиболее оптимальным способом максимально возможно усовершенствовать технологию извлечения нативного крахмала, а также во многом отказаться от технологий химической модификации является использование (учитывание) в технологиях глубокой переработки крахмалосодержащего растительного сырья основополагающего научного принципа, который гласит что «структура вещества определяет (обуславливает) проявляемые им свойства».

Согласно полученных нами результатов, а также известных данных $[1 ; 6$; $7 ; 12$-14] крахмальные зерна имеют овальную, сферическую или неправильную форму, их диаметр колеблется в пределах $0,001-0,2$ мм. Крахмальные зерна разделяются на простые и сложные: простые зерна представляют собой однородные образования; сложные - сочетание более мелких частиц. Плотность крахмала равна в среднем 1,5 кг/ $\mathrm{m}^{3}$ [3].

На основании анализа особенностей строения нативного крахмала можно сделать предположение, что основной структурной характеристикой строения нативного крахмала, обуславливающей его свойства, является крахмальное зерно (гранула). Так, особенности размера и формы крахмальных зерен 
обуславливают (определяют) проявление следующих свойств (характеристик) крахмала:

- количество связанной влаги (чем больше крахмальная гранула, тем больше связанной влаги имеется в крахмале и наоборот);

- температуру клейстеризации (чем больше крахмальная гранула, тем меньше температура ее клейстеризации и наоборот);

- соотношение крахмальных фракций разветвленной фракции амилопектина и линейной амилозы (формирование крахмальной гранулы обусловлено взаимодействием линейных участков амилопектина друг с другом или с амилозой);

- реологические характеристики крахмального клейстера (вязкость крахмального клейстера обусловлена соотношением крахмальных фракций амилопектина и амилозы).

Температура клейстеризации, количество связанной влаги, вязкость крахмального клейстера, соотношение крахмальных фракций, цвет йодной пробы и другие физико-химические свойства обуславливают (определяют) особенности размера и формы крахмальных зерен.

\section{Выводы}

1. Основной структурной характеристикой строения нативного крахмала, обуславливающей его физико-химические свойства, является крахмальное зерно (гранула).

2. Выявлено большое разнообразие форм крахмальных зерен. Были идентифицированы крахмальные зерна правильной и неправильной овальной, округлой, многогранной формы.

3. Размеры крахмальных зерен колебались в следующих пределах: $60,0-$ 0,5 мкм. Исследованные нативные крахмалы в зависимости от среднего размера крахмальных зерен можно расположить в ряд по уменьшению (мкм): картофельный $(21,7 \pm 1,22)$, ржаной $(21,2 \pm 2,36)$, гороховый $(20,4 \pm 2,57)$, нутовый $(14,8 \pm 0,93)$, тритикалевый $(13,2 \pm 1,75)$, пшеничный $(12,4 \pm 1,90)$, сорговый $(11,0 \pm$ $\pm 0,76)$, ячменный $(10,9 \pm 1,15)$, тапиоковый $(10,6 \pm 0,50)$, кукурузный $(9,8 \pm 0,42)$, овсяный $(7,39 \pm 0,87)$, рисовый $(5,3 \pm 0,29)$, амарантовый $(1,1 \pm 0,04)$. Наибольший размер крахмальных зерен был отмечен у картофельного крахмала, а наименьший размер - у амарантового крахмала.

4. Установлено, что у семи нативных крахмалов (соргового, ячменного, овсяного, горохового, нутового, амарантового и кукурузного) распределение крахмальных зерен по размерам мономодальное (1-фракционное), у четырех (пшеничного, тритикалевого, картофельного и тапиокового) - бимодальное (2фракционное), у двух (ржаного и рисового) - тримодальное (3-фракционное).

\section{Литература}

1. Ловкис 3.В. Технология крахмала и крахмалопродуктов: Учеб. пособ. / З.В. Ловкис, В.В. Литвяк, Н.Н. Петюшев; РУП «Научно-практический центр Национальной академии наук Беларуси по продовольствию». — Минск : Асобный, 2007. — 178 с.

2. Полумбрик М.О. Углеводы в пищевых продуктах / М.О. Полумбрик, В.В. Литвяк, 3.В. Ловкис, В.Н. Ковбаса. — Минск: ИВЦ Минфина, 2016. — 592 с.

3. Справочник по крахмало-паточному производству / Д.Р. Абрагам [и др.]; под ред. Е.А. Штырковой, М.Г. Губина. — Москва : Пищевая промышленность, 1978. — 430 с. 
4. Крахмал и крахмалопродукты / Н.Г. Глюк, А.И. Жушман, Т.А. Ладур, Е.А. Штыркова. - Москва : Агропромиздат, 1985. - 240 с.

5. Химия и технология крахмала: Промышленные вопросы: пер. с англ.: под ред. Роя Л. Уилстера и Энжена Ф. Пашаля. - Москва : Пищ. пром-сть, 1975. — 360 с.

6. Керр Р.В. Химия и технология крахмала / Р.В. Керр, Ж.В. Цезар, Л.М. Кристенсен и др.; под ред. Р.В. Керра; пер. с англ. - Москва : Пищепромиздат, 1956. - 579 с.

7. Андреев Н.Р. Основы производства нативных крахмалов. - Москва : Изд.: Пищепромиздат, 2001. - С. 289.

8. Жушман А.И. Модифицированные крахмалы / А.И. Жушман. - Москва: Пищепромиздат, 2007. - 236 с.

9. Крахмал картофельный. Технические условия: ГОСТ 7699-78. - Утвержден и введен в действие Постановлением Государственного комитета СССР по стандартам от 18.10.1978 № 2709. — Москва, 1978. — 6 с.

10. Крахмал кукурузный. Технические условия: ГОСТ 7697-82. - Утвержден и введен в действие Постановлением Государственного комитета СССР по стандартам от 12.02.1982 № 584. - Москва, 1982. — 5 с.

11. Рокиџкий П.Ф. Биологическая статистика / П.Ф. Рокицкий. - Минск, Выш. шк., 1973. - $320 \mathrm{c}$.

12. Кретович В.Л. Биохимия растений: учеб. / В.Л. Кретович. - Москва: Высш. шк., 1986. - $503 \mathrm{c}$.

13. Литвяк В.В. Атлас: морфология полисахаридов / В.В. Литвяк, Г.Х. Оспанкулова, Д.А. Шаймерденова, Н.К. Юркштович, С.М. Бутрим, Ю.Ф. Росляков. - Астана : ТОО «EDIGE», 2016. - $335 \mathrm{c}$.

14. Литвяк В.В. Крахмал и крахмалопродукты: монография / В.В. Литвяк, Ю.Ф. Росляков, С.М. Бутрим, Л.Н. Козлова; под ред. д-ра техн. наук, профессора Ю.Ф. Рослякова. Краснодар : Изд. ФГБОУВПО «КубГТУ», 2013. — 204 с.

15. Костенко В.Г. Производство крахмала / В.Г. Костенко, А.Е. Овчинников, В.М. Горбатов. - Москва : Легкая и пищевая промышленность, 1983. - 200 с. 